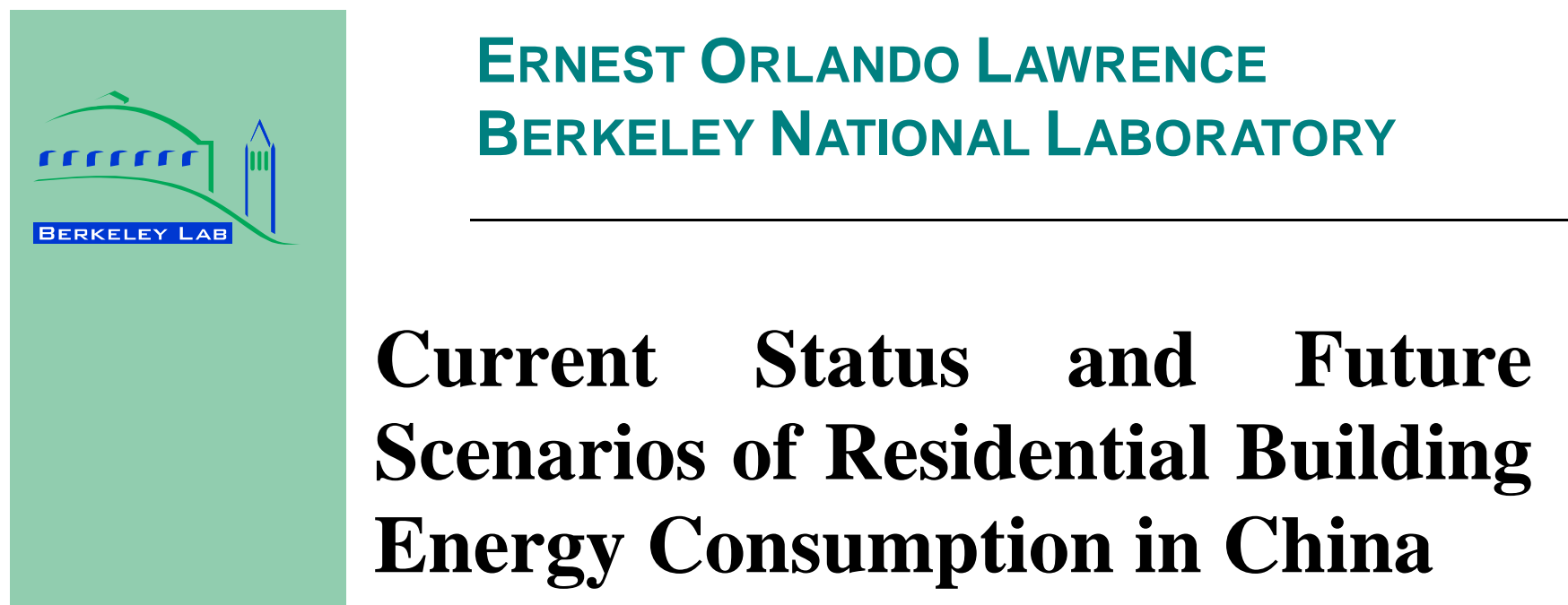

Nan Zhou

Environmental Energy

Technologies Division

Masaru Nishida

Department of Architecture

Kyushu Sangyo University

Weijun Gao

Department of Environment Space Design

The University of Kitakyushu

December 2008

This work was supported by the U.S. Department of Energy under Contract No. DE-AC02-05CH11231. 


\section{Disclaimer}

This document was prepared as an account of work sponsored by the United States Government. While this document is believed to contain correct information, neither the United States Government nor any agency thereof, nor The Regents of the University of California, nor any of their employees, makes any warranty, express or implied, or assumes any legal responsibility for the accuracy, completeness, or usefulness of any information, apparatus, product, or process disclosed, or represents that its use would not infringe privately owned rights. Reference herein to any specific commercial product, process, or service by its trade name, trademark, manufacturer, or otherwise, does not necessarily constitute or imply its endorsement, recommendation, or favoring by the United States Government or any agency thereof, or The Regents of the University of California. The views and opinions of authors expressed herein do not necessarily state or reflect those of the United States Government or any agency thereof, or The Regents of the University of California.

\section{Ernest Orlando Lawrence Berkeley National Laboratory is an equal opportunity employer.}




\title{
Current Status and Future Scenarios of Residential Building Energy Consumption in China
}

\author{
Nan Zhou*, Masaru Nishida, and Weijun Gao
}

\begin{abstract}
China's rapid economic expansion has propelled it into the ranks of the largest energy consuming nation in the world, with energy demand growth continuing at a pace commensurate with its economic growth. Even though the rapid growth is largely attributable to heavy industry, this in turn is driven by rapid urbanization process, by construction materials and equipment produced for use in buildings. Residential energy is mostly used in urban areas, where rising incomes have allowed acquisition of home appliances, as well as increased use of heating in southern China. The urban population is expected to grow by 20 million every year, accompanied by construction of 2 billion square meters of buildings every year through 2020. Thus residential energy use is very likely to continue its very rapid growth. Understanding the underlying drivers of this growth helps to identify the key areas to analyze energy efficiency potential, appropriate policies to reduce energy use, as well as to understand future energy in the building sector.

This paper provides a detailed, bottom-up analysis of residential building energy consumption in China using data from a wide variety of sources and a modeling effort that relies on a very detailed characterization of China's energy demand. It assesses the current energy situation with consideration of end use, intensity, and efficiency etc, and forecast the future outlook for the critical period extending to 2020, based on assumptions of likely patterns of economic activity, availability of energy services, technology improvement and energy intensities.
\end{abstract}

Keywords: China, residential building, modeling, energy intensity, energy efficiency, scenario

*This work was supported by the U.S. Department of Energy under Contract No. DE-AC02-05CH11231. 


\section{Introduction}

China's Medium and Long-Term Development plan drafted by the central government and published in 2004 (NDRC,2005) laid out the broad guidelines of China's development from 2000 to 2020 , central to which is a quadrupling of GDP with only a doubling of energy consumption. This goal is in essence to repeat the experience of the period from 1980 to 2000 when China did achieve a quadrupling of GDP while keeping energy consumption growth to only half that rate. By 2005, however, it became apparent that China had substantially exceeded its energy consumption growth target for the first quarter of its 20-year development plan. Instead of maintaining the ratio of energy growth to economic growth at 0.5 , China experienced a sharp rise in energy intensity between 2001 and 2005, This loss of momentum in continued efficiency gains and intensity reduction called into question China's ability to keep energy consumption growth at just half the rate of economic growth over the entire 20 year period and suggested that energy consumption in 2020 would be significantly higher than forecast.

In an early study, we have undertaken a detailed analysis of recent energy intensity trends in China, revealing the dominant role of rampant growth in heavy industries as the leading cause of recent increases in China's energy intensity (Lin, 2007). Even though the rapid growth is largely attributable to heavy industry, this in turn is driven by rapid urbanization process, by construction materials and equipment produced for use in buildings. Residential energy is mostly used in urban areas, where rising incomes have allowed acquisition of home appliances, as well as increased use of heating in southern China. The urban population is expected to grow by 20 million every year, accompanied by construction of 2 billion square meters of buildings every year through 2020. Thus residential energy use is very likely to continue its very rapid growth. Understanding the underlying drivers of this growth helps to identify the key areas to analyze energy efficiency potential, appropriate policies to reduce energy use, as well as to understand future energy in the building sector.

As a sequence of the research published early on commercial energy use in China (Zhou,2008), this paper provides a detailed, bottom-up analysis of residential building energy consumption in China using data from a wide variety of sources and a modeling effort that relies on a very detailed characterization of China's energy demand. It assesses the current energy situation with consideration of end use, intensity, and efficiency etc, and forecast the future outlook for the critical period extending to 2020, based on assumptions of likely patterns of economic activity, availability of energy services, technology improvement and energy intensities.

The primarily analytical tool used in this study was a accounting framework of China's energy and economic structure, built using the LEAP (Long-Range Energy Alternatives Planning) modeling software. 


\section{Methodology}

Residential energy demand is shaped by a variety of factors, including location (in both geographic location and urban vs. rural) and climate. In developing countries such as China, it is important to divide households into rural and urban locales due to the different energy consumption patterns found in these locations. Within the locales, end uses were broken out into space heating, air conditioning, appliances, cooking and water heating, lighting, and a residual category.

The end uses were further broken out by technologies; some appliances were broken out into classes by level of service, associated with different levels of efficiency. Space heating varies by climate type, so it is broken out by North, Transition and South zones. For all end uses, appropriate devices and fuels were assigned, with saturation (rates of penetration) and energy efficiencies based on statistical and survey data pertaining to the base year (2000) and future values based on analysis of government plans, trends, and comparisons to other countries. Changes in energy demand in the model are in part a function of driver variables, e.g., GDP, population, and household size, which were determined exogenously and included in the model. Table 1shows the breakouts.

The equation for energy consumption in residential buildings can be summarized as follows (some subscripts have been omitted for brevity of presentation):

Equation 1.

$E_{\text {RB }}=\sum_{i}^{\text {oprov orñoN }} \sum_{m} \frac{P_{m, i}}{F_{m, i}} \times\left[\left(H_{m, i} \times\left(S H_{m, i}\right)\right)+\left(\sum_{j} p_{i, j, m} \times U E C_{i, j, m}\right)+C_{m, i}+W_{m, i}+L_{m}+R_{m}\right]$

where, in addition to the variables listed above:

$m \quad$ =locale type (urban, rural)

$P m, i=$ population in locale $m$ in region $i$

$F m, i=$ number of persons per household (family) in locale $m$ in region $i$,

$H m, i=$ average floor area per household in locale type $m$ in region $i$ in $m 2$

$\mathrm{SHi}=$ space heating energy intensity in residential buildings in region $\mathrm{i}$ in $\mathrm{kWh} / \mathrm{m} 2-y e a r$,

$j \quad=$ type of appliance or end-use device,

pi,j = penetration of appliance or device $j$ in region $i$ in percent of households owning appliance (values in excess of $100 \%$ would indicate more than one device per household on average),

$U E C i, j=$ energy intensity of appliance $j$ in region $i$ in $M J$ or $k W h / y e a r$,

$\mathrm{Ci} \quad$ =cooking energy use per household in region $\mathrm{i}$ in MJ /household-year,

$W i \quad=$ water heating energy use per household in region $i$ in MJ /household-year,

Lm =average lighting energy use per square meter in locale type $i$ in $\mathrm{kWh} /$ square meter-year, and

$R m=$ residual household energy use in locale type $i$ in MJ /household-year.

Air conditioner and refrigerator end uses are detailed with stock turnover modeling, which includes information on initial stocks by vintage, energy efficiencies by vintage (allowing explicit modeling of the impacts of standards), efficiency degradation profiles, and lifetime or survival 
profiles.

\section{Current Residential Building Energy Consumption in China}

\subsection{Assumptions of the Drivers}

Along with population size, key activity drivers of energy and demand in residential buildings are rate of urbanization, number of households, per capita living area, persons per residence. In the residential buildings sector, the level of energy demand is further influenced by household income, number of households, and the size of households. Although GDP is not a direct driver in our analysis, it is however used as reference to drive the increase of living area and saturation of appliances.

The key drivers used in our disaggregating effort are presented in Table 2. The population in 2000 is 1.27 billion and $34.3 \%$ of them live in north China, $30 \%$ in the South, with the rest live in transitional area. The regional split is used to estimate the energy demand in each region according to climate differences differs and determine the level of the space heating and space cooling needs. The number of people living in urban areas in China is $35.6 \%$ of the total, which is almost the level of the world average in 1970 (U.N. 2005). Historically, the average household size has been declining in most of the developing countries. China adopted one child policy in 1979 which accelerated this decrease. Average household size declined from 5 persons in 1980 to 3.7 persons in 2004, and in urban China it has almost reached the level of developed countries. Change in household size is important because per capita energy use rises as household size decreases (Schipper and Meyers, 1992). Another important factor is the dwelling area. Dwelling area in China has increased significantly over the past two decades with an AGR of $4.3 \%$ while it is only about $0.6 \%$ in other countries. In 2000, the average dwelling area in China was $94 \mathrm{~m}^{2}$ per dwelling on average, which has already reached many of the developed countries level in 1998(IEA, 2004).

\subsection{Energy Use and Activity}

We summarize the saturation and aggregated energy intensity on each of the main residential energy end uses in Table 3. Heating equipment has been used throughout northern China, but only $30 \%$ of the urban area and $8 \%$ of the rural area in transition area has heating devices. In northern urban areas, stoves and boilers are the major heating equipment with a share of $40 \%$ respectively, followed by district heating of $22 \%$, while in rural, biomass is the major heat source, with a share of $85 \%$. In central China, electric heaters are the major heating with the share of $60 \%$ (Zhou, 2003). Buildings in North and Transition urban area are supposed to meet the 2001 building codes. Space heating intensity is $31.60 \mathrm{~W} / \mathrm{m}^{2}$-degree day in north and $17.5 \mathrm{~W} / \mathrm{m}^{2}$-degree day in transition region in 2000. Rural China has much lower heating intensity because of the income gap with urban, which is $2.34 \mathrm{~W} / \mathrm{m}^{2}$--degree day in north and $0.14 \mathrm{~W} / \mathrm{m}^{2}$-degree day in transition region in 2000.

Cooking and water heating intensity in urban areas is $1252 \mathrm{kWh} /$ household per year and slightly more in rural areas. This is much lower than that of Japan in 2000 which was $4560 \mathrm{kWh} /$ household (IEEJ, 2003). In developed countries, the energy consumption of water heating is approximately 5 times as much as that of cooking. Water heating energy is 4.7 higher than cooking energy in the U.S. 
and UK, and 4.22 times higher for Japan in 2000 (IEEJ, 2003). We assume that a similar ratio also applies for China. LPG is a major energy source, while coal and electricity are also used in some parts of China. Biomass is the major energy in rural area.

For lighting, an aggregated lighting intensity was used (Lin, 2003). The annual lighting energy intensity for 7 major cities in China is $213 \mathrm{kWh} /$ household in 1999. The share for different bulbs is $55 \%$ for incandescent, $39 \%$ for fluorescent and $6 \%$ for CFL (compact fluorescent).

Energy use in appliances is determined by ownership or saturation rate and the unit energy consumption (UEC). Ownership rates often grow as a result of economic development. In 2000, refrigerators, TV and clothes washers have already penetrated much of the households in urban areas, while the rates in rural area are still much lower. The use of air conditioning is highly dependent on the climate as well as the income level, therefore on average the ownership is only about 30\% in urban China, and very rare in rural. These numbers are much lower than those of developed countries such as $121 \%$ for refrigerator and $217.4 \%$ for air conditioner in Japan in 2000 (IEEJ, 2003). In addition, change in the size and features of appliances plays a major role in determining the UECs. Increases in average size are most significant for refrigerators. Table 3 also shows that most of UECs of the appliances are higher those of Japan, indicating a large potential for energy efficiency improvement.

\subsection{Energy consumption by fuel and end-use}

The adjusted residential energy consumption was 6.6 EJ in 2000, accounting for $16 \%$ of primary energy without counting biomass fuels (Figure 2). It would be $30.6 \%$ if biomass is counted. This figure is four percentage points higher than what is reported in China's statistic, and the reason has been addressed in an early article (Zhou, 2008). The energy is mostly used in urban area because the rising income have allowed acquisition of home appliances, in addition to the existing central heating system in northern China, which resulted in much larger share of electricity, coal and gas use. Despite the larger share of land area and more population $(64.4 \%)$ in rural China, the primary energy use is only $1.84 \mathrm{EJ}$, accounting for $28 \%$ of the total residential energy use.

Besides biomass, coal is the dominant fuel, accounting for $79 \%$ of non-biomass energy consumption in households (Figure 3and Figure 4). This includes the coal direct use for heating and coal used to generate electricity used for appliances. Oil use (principally kerosene) is mostly seen in rural lighting. Even though renewable energy has increased drastically, its share remains insignificant $(0.2 \%)$.

Most of the energy was used for space heating and water heating, accounting for 59\% of the residential energy consumption (Figure 1). The four major appliances including air conditioner, refrigerator, clothes washer and TV use about $21 \%$ of household energy, followed by lighting at $9 \%$ and cooking at $7 \%$. Other use which accounts for residual appliances such as computers, printers, etc.., uses only $4 \%$ of energy in 2000. 
While energy demand for space heating naturally varies with the climate; it is also determined by the household income level and other factors. Many households in China do not have sufficient heating due to poverty, and traditionally, there were no heating supply system in Southern China, where the temperature can get very low in the winter. These all possibly contributed to the lower share of space heating demand in China in 2000. 
Table 1 End-Use Structure of the Residential Sector

\begin{tabular}{|c|c|c|c|c|c|c|c|c|}
\hline End use & \multicolumn{2}{|c|}{ Space heating } & \multirow{2}{*}{$\begin{array}{l}\text { Air } \\
\text { conditioning }\end{array}$} & \multirow[t]{2}{*}{ Lighting } & \multirow{2}{*}{$\begin{array}{l}\text { Cooking and } \\
\text { water heating }\end{array}$} & \multicolumn{3}{|l|}{ Appliances } \\
\hline Category & North & Transition & & & & Clothes Washer & TV & $\begin{array}{l}\text { Refrigerator } \\
\text { Three sizes }\end{array}$ \\
\hline $\begin{array}{l}\text { Technolo } \\
\text { gies }\end{array}$ & $\begin{array}{l}\text { Electri } \\
\text { gas bc } \\
\text { boiler } \\
\text { stove } \\
\text { distric } \\
\text { heat } p \\
\text { condit }\end{array}$ & $\begin{array}{l}\text { leater } \\
\text { eating } \\
\text { p air } \\
\text { er }\end{array}$ & $\begin{array}{l}\text { Ordinary } \\
\text { efficient } \\
\text { Highly } \\
\text { efficient }\end{array}$ & $\begin{array}{l}\text { Incandescen } \\
\mathrm{t} \\
\text { Florescent } \\
\text { CFL }\end{array}$ & $\begin{array}{l}\text { Electricity } \\
\text { Natural gas } \\
\text { LPG } \\
\text { Coal } \\
\text { Coal gas } \\
\text { Other }\end{array}$ & $\begin{array}{l}\text { Vertical } \\
\text { Horizontal }\end{array}$ & $\begin{array}{l}\text { Black } \\
\text { TV } \\
\text { Color } \\
\text { TV }\end{array}$ & $\begin{array}{l}\text { Ordinary } \\
\text { efficient Highly } \\
\text { efficient }\end{array}$ \\
\hline
\end{tabular}

Table 2 Macro Drivers in Residential Sector

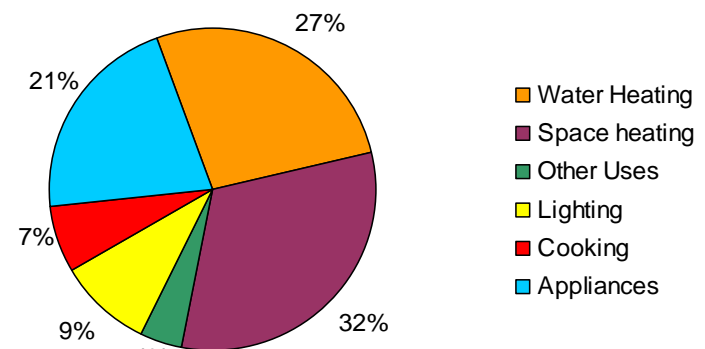

Figure 1 Residential Energy consumption by End-use

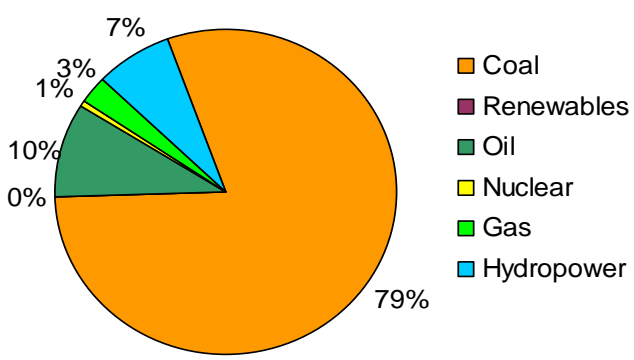

Figure 2 Residential Primay Energy Consumption by Fuel

Table 3 End Use Saturations and Intensities

\begin{tabular}{|c|c|c|c|c|c|c|c|}
\hline & \multicolumn{2}{|c|}{ Saturation, \% } & \multicolumn{5}{|c|}{ End use intensity/UEC } \\
\hline & Urban & Rural & Unit & Urban & Rural & Japan & notes \\
\hline \multicolumn{8}{|l|}{ Space Heating } \\
\hline North & 100 & 100 & $\mathrm{kWh} / \mathrm{m}^{\wedge} 2$-year & 79 & 5.9 & 386 & 2000 average \\
\hline Transition & 30 & 8 & $\mathrm{kWh} / \mathrm{m}^{\wedge} 2$-year & 26.6 & 0.24 & & \\
\hline Refrigerator & 80 & 12 & kWh/year & 460 & 460 & 380 & $\begin{array}{l}2004 \text { for } \\
250 \mathrm{~L}-300 \mathrm{~L}\end{array}$ \\
\hline Clothes washer & 91 & 29 & & & & & \\
\hline vertical & 63 & 70 & $\mathrm{kWh} /$ year & 36 & 36 & $\begin{array}{l}21.9 \\
\text { to }\end{array}$ & 2004 for $4.2 \mathrm{~kg}$ \\
\hline horizontal & 27 & 30 & $\mathrm{kWh} /$ year & 61 & 61 & 40.2 & \\
\hline \multicolumn{8}{|l|}{ TV } \\
\hline black & 0 & 53 & kWh/year & 38 & 38 & & \\
\hline color & 117 & 49 & $\mathrm{kWh} /$ year & 150 & 150 & 79 & 2004 for 29 inch \\
\hline Air Conditioner & 31 & 1 & kWh/year & 388 & 375 & 229 & 2000 average \\
\hline $\begin{array}{l}\text { Cooking and water } \\
\text { heating }\end{array}$ & - & - & MJ/household-year & 4506 & 4986 & 16420 & 2000 average \\
\hline Other use & - & - & kWh/year & 280 & 100 & 16546 & 2000 averaco \\
\hline lighting & - & - & kWh/household & 283 & 253 & 10540 & 2000 average \\
\hline
\end{tabular}




\section{Future outlook for Energy Use in China}

\subsection{Activity and structural change}

\subsubsection{Population and Urbanization}

Urban population in China increased between 1980 and 2000, growing from 193 million, or $19.5 \%$ of the total in 1970 to 451.8 million, or $35.6 \%$ of total in 2000 and is projected to increase to $55.8 \%$ in 2020 (UN, 2003). Total population will still grow, but at a much slower pace compared with that of years pre 2000 , at $0.5 \%$ per year. Increasing urbanization leads to the increased use of commercial fuels, such as natural gas and LPG, for cooking instead of traditional biomass fuels. Additional increases in energy use come with electrification, when appliances and lighting are adopted.

\subsubsection{Residential Living Area and Household Size}

Globally, the size of the household tends to decline with increasing income and urbanization of the population. In the case of China, the "one child policy" enforced such a decline particularly rigorously. Average household size in China dropped from 5.2 persons in 1981 to 3.04 persons per household in 2002 ( Figure 3 ). And this trend is expected to continue, with urban household size decreasing from 3.13 persons in 2000 to 2.88 persons/household in 2020, the level of Japanese household size today. It is also assumed that rural household size will be 3.9 persons/household in 2020.

In China, floor space per person increased from $9.9 \mathrm{~m}^{2}$ to $19.8 \mathrm{~m}^{2}$ in urban and from $17.8 \mathrm{~m}^{2}$ to $24.8 \mathrm{~m}^{2}$, from 1990 to 2000 . In 2030, it is assumed to be equal to the current size in Japanese households ( $30 \mathrm{~m}^{2} /$ capita) while rural residences will have $34.8 \mathrm{~m}^{2} /$ capita).

The decline in household size leads to an increase in the total number of households in the region, which, together with the increase in living area will multiply the contribution of energy demand from households.

\subsubsection{Residential Appliance Penetration Change}

Ownership of the four major electric appliances-refrigerators, air conditioners, clothes washers and TVs increased significantly from 1981 to 2000 except for black \& white TVs. For example, refrigerator ownership started at $1 \%$ in 1981 and increased to $80.1 \%$ in 2000 in urban China. Increased income levels and decreasing appliance prices drive the growth of the ownership of appliances, but will slow down when reaching a high saturation rate. In urban areas, color TV is already universal; clothes washer ownership is approaching saturation; and refrigerator rates are also growing. All of these will result in a much slower pace of growth of appliance ownership through 2020, and therefore will have much smaller impact on household electricity consumption in the future. Other factors such as air conditioning is an exception because it began to appear in early 90s, and is expected continue growing much faster. The level of energy required for urban households in China in 2020 is assumed to be similar to that consumed in urban households in Japan today. For appliance saturation, it is assumed that urban Chinese households will reach the level of appliance ownership of Japan today by 2020(Figure 4). 


\subsubsection{End Use Intensities}

Table 4 shows the values for major driver variables that were used to obtain an outcome to 2020 . Energy intensity for cooking, water heating and lighting will increase to accommodate the demand for higher level of comfort. These intensities are still low compared to other countries, whereas space heating stands out as an exception. Space heating in Northern urban China is predominately supplied through district heating system that does not have meters or switches installed in individual houses, resulting in imbalances and inability to control heat use, forcing consumers to commonly open windows as the only means to regulate overheating. In addition, current building codes is not stringent enough compared with other countries (Zhou, 2008), and the enforcement is far from being adequate. In southern cities, the compliance rate in new buildings could be as low as 8 to $10 \%$. With the adoption of the heat metering system and the building envelope improvement, we project the efficiency of the heating utilization in northern urban region will significantly improve on both these fronts therefore lead to a decline in heating intensity. The transition area (areas south of Yangzi river but north of the non-heating Southern China) and rural China on the other hand, where defined as "non-heating zone", historically has had no heating equipment, will demand for more heating as their economy develops. This will result in growing intensity in space heating.

\subsection{Energy efficiency}

The energy efficiency in our model is a combination of the efficiency and market shares of different types of technologies. Our analysis reveals that the efficiency of the different technology will be improved over time due to the revision of minimum energy efficiency standard as well as technology development. Figure 5 illustrates an example of the efficiency change of space heating technology. For instance, the average efficiency of the district heating will increase by 23 percent, whereas a heat pump shows a 80 percent improvement potential.

At the same time, the market share of efficient and cleaner technology also rises according to the current government policy (Figure 6). Technologies such as conventional coal boilers and district heating will gradually shift to cleaner gas boilers and more efficient heat pumps. The projection is based on assumption that both the efficiency and market shares of the different technologies used in the Chinese residential sector will converge to their current level in Japan by 2020.

Because of their large share in household energy use, refrigerators and air conditioners were modeled in some detail. They were broken out into efficiency classes (and also, in the case of refrigerators, size classes) and simple stock turnover modeling was implemented. The case of refrigerators in urban households provides an example of how the efficiency changes overtime.

Current data for actual refrigerators on the Chinese market and information on possible future efficiency standards (China National Institute of Standardization, 2003) are used to determine efficiency levels for these three efficiency classes in each of three typical refrigerator sizes (170 liters, 220 liters, and 270 liters). Average intensity levels for the three efficiency classes, which are assumed to decline over the 2000 to 2030 period are shown in Error! Reference source not 
found.Figure 7. Error! Reference source not found.Figure 8 shows that, over the period of the scenario, the average size of new refrigerator is assume to rise. The rise of the size of refrigerators therefore offsets the efficiency improvements in each size category, that the average unit energy consumption of refrigerators shown in Table 4 would have more significant reduction otherwise.

\subsection{Future Energy Outlook}

Growth in residential and commercial energy consumption is driven both by an increase in total floor space devoted to these uses and by the increase in appliance, lighting, and heating and cooling usage in these areas (Error! Reference source not found.Figure 9, and Error! Reference source not found.Figure 10). As urbanization increases, growing from the current $40 \%$ to $56 \%$ in 2020 , and household wealth continues to rise, demand in households for refrigerators, air conditioners, lighting products, clothes washers, consumer electronics, space heating, water heating and other functions will increase substantially. For example, the average efficiency of an "efficient" split-type room air conditioner in urban households is expected to improve by nearly $40 \%$ by 2020 over the 2004 level, but owing to continued high rates of sales, total electricity consumption by "efficient" room air conditioners is expected to more than triple, from 12 TWh in 2004 to 38 TWh in 2020.

By 2012, the total energy consumption of the 650 million urban residents will surpass that of the 728 million rural residents, even considering the $5.8 \mathrm{EJ}$ consumed in rural households in the form of biomass. In terms of just commercial energy, urban household consumption will be three times that of rural areas. This high continued reliance on biomass for rural energy consumption shows the potential challenge to the coal, oil, gas and electricity sectors of fully displacing biomass usage in rural households.

As living standards rise, energy efficiency improvements in the building sector are likely to be offset by the growing demand for higher levels of energy services: more space heating and cooling, improved lighting, and larger appliances. These responses to higher living standards make it difficult to reduce energy intensity in building sector. In 2020, residential building energy consumption will reach $15.86 \mathrm{MJ}$ from $6.6 \mathrm{MJ}$ in 2000 , with a $4.5 \%$ growth rate per year.

\section{Conclusions}

This paper provides a bottom-up analysis of residential building energy consumption in China using data from a variety of sources and a modeling effort that relies on a very detailed characterization of China's energy demand. The results can be summarized as the following:

The adjusted residential energy consumption was $6.6 \mathrm{EJ}$ in 2000, accounting for $16 \%$ of primary energy, in which, urban energy use accounts for $72 \%$ of the total residential energy and coal is the dominant fuel. Most of the energy was used for space heating and water heating, accounting for $59 \%$ of the residential energy consumption. The four major appliances including air conditioner, refrigerator, clothes washer and TV use about $21 \%$ of household energy, followed by lighting at $9 \%$ and cooking at $7 \%$. 
In 2020, residential building energy consumption will reach 15.86 MJ from 6.6 MJ in 2000, with a $4.5 \%$ growth rate per year. The growth is mainly driven by increasing urbanization together with the increase in living area will multiply the contribution of energy demand from households. As living standards rise, energy efficiency improvements in the building sector are likely to be offset by the growing demand for higher levels of energy services. These responses to higher living standards make it difficult to reduce energy intensity in building sector. Increased income levels and decreasing appliance prices drive the growth of the ownership of appliances, but will slow down when reach a high saturation rate. Average intensity levels are assumed to decline over the 2000 to 2020, whereas the average size of new refrigerator is assume to rise. By 2012, the total energy consumption of the urban residents will surpass that of rural residents, even considering the 5.8 EJ consumed in rural households in the form of biomass. This high continued reliance on biomass for rural energy consumption shows the potential challenge to the coal, oil, gas and electricity sectors of fully displacing biomass usage in rural households.

\section{References}

1) Battles, S., and Burns, E., 2000. Trends in Building-Related Energy and Carbon Emissions: Actual and Alternate Scenarios, Summer Study on Energy Efficiency in Buildings, August 21, Washington, DC: American Council for an Energy-Efficient Economy.

2) Brockett,D., Fridley, D., Lin,JM, and Lin, J 2003. A Tale of Five Cities: The China Residential Energy Consumption Survey, Human and Social Dimension of Energy Use: Understanding Markets and Demand

3) Committee of RNECSPC, 2005. Research on National Energy Comprehensive Strategy and Policy of China (RENESPEC), Economic Science Press.

4) Institute of Energy Economics, Japan (IEEJ), 2003. Handbook of Energy \& Economic Statistics in Japan, he Energy Data and Modeling Center, The Institute of Energy Economics, Tokyo, Japan

5) International Energy Agency (IEA),2004. 30 Years of Energy Use in IEA Countries, Paris: IEA/OECD.

6) Lin, J, 2003. A Light Diet for a Giant Appetite: An Assessment of China's Fluorescent Lamp Standard, Energy, No.30, pp8-35

7) Lin, Jiang, Zhou, Nan, Levine, Mark, and Fridley, David. Taking out one billion tons of CO2: the magic of China's 11th five year plan? Energy Policy, No. 26. 2008, December 2007. LBNL-757E.

8) Nadel, S.M., Fridley, D., Sinton, J., Zhirong, Y., Hong, L., 1997. Energy Efficiency Opportunities in the Chinese Building Sector. Washington, DC: American Council for an Energy-Efficient Economy.

9) National Bureau of Statistics of China (NBS), 1981-2005. China Statistical Yearbooks. Beijing: Info Press. http://www.stats.gov.cn/english/statisticaldata/yearlydata/

10) National Development and Reform Commission (NDRC), 2005. Medium- and Long-term Conservation Plan, China Environmental Science Press, Beijing.

11) Sathaye, J., Ketoff, A., Schipper, L., and Lele, S., 1989. An End-Use Approach to Development of Long-Term Energy Demand Scenarios for Developing Countries, Berkeley, CA, LBNL (LBL-25611).

12) Schipper, L., Meyers, S., Howarth, R., and Steiner, R., 1992. Energy Efficiency and Human Activity, Cambridge University Press, Cambridge: UK

13) United Nations (UN), 2003. World Population Prospects: The 2002 Revision, United Nations Population Division. www.unpopulation.org.

14) United Nations, 2005. World Population Prospects: The 2005 Revision. Department of Economic and Social Affairs. Population Division. 
15) Zhou, D., Dai,Y., Yu, C., Guo, Y. and Zhu,Y., 2003. China's Sustainable Energy Scenarios in 2020, China Environmental Science Publishing Company.

16) Zhou, Nan and Lin, Jiang. 2008, The Reality and Future Scenarios of Commercial Building Energy Consumption in China, 2008, Energy\& Buildings, June Volume 40, Issue 12, Pages 2121-2127 


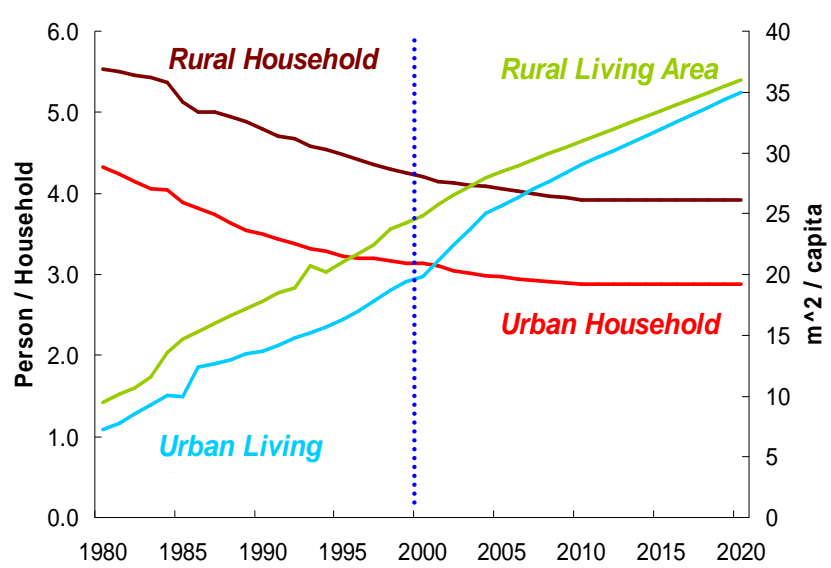

Figure 3 Floor area per Capita and Household Size Trend

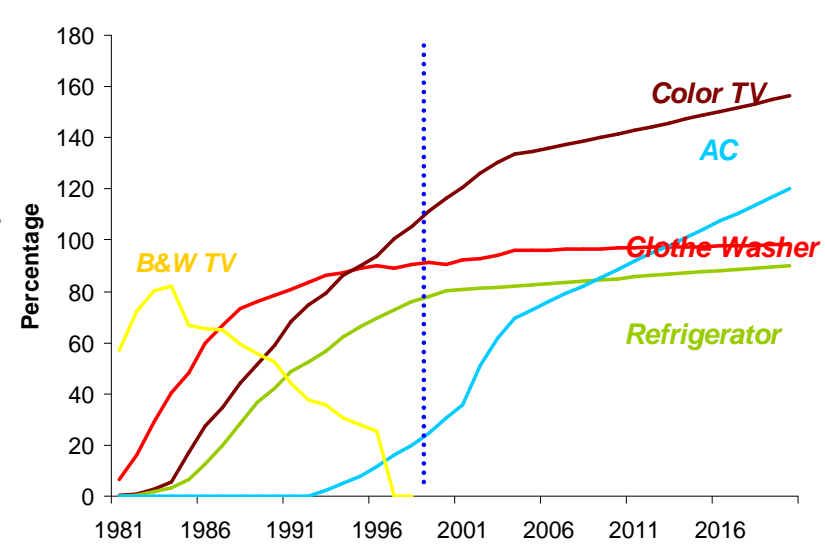

Figure 4 Urban Appliance Ownership

Table 4 Residential Energy Intensity by End-use Assumptions

\begin{tabular}{|c|c|c|c|c|c|c|c|}
\hline & & \multicolumn{2}{|c|}{$\begin{array}{l}\text { Urban enduse } \\
\text { intensity }\end{array}$} & \multicolumn{2}{|c|}{$\begin{array}{l}\text { Rural enduse } \\
\text { intensity }\end{array}$} & \multirow{2}{*}{$\begin{array}{c}\text { Japanese } 2004 \\
\text { most efficient } \\
\text { technology }\end{array}$} & \multirow[b]{2}{*}{ note } \\
\hline & & & & & 2020 & & \\
\hline \multicolumn{8}{|l|}{$\overline{\text { Space Heating }}$} \\
\hline North & $\mathrm{kWh} / \mathrm{m}^{\wedge} 2$-year & 79 & 64 & 5.85 & 30.6 & & \\
\hline Transition & $\mathrm{kWh} / \mathrm{m}^{\wedge} 2$-year & 29.6 & 28.8 & 5 & 9.6 & & \\
\hline Cooking & MJ/household-year & 901.2 & 1421 & 997 & 1349 & & \\
\hline water heating & MJ/household-year & 3605 & 5685 & 3988 & 5396 & & \\
\hline Other use & kWh/year & 100 & 420 & 50 & 150 & & \\
\hline lighting & $\mathrm{kWh} / \mathrm{m}^{\wedge} 2$-year & 3 & 4.5 & 1.5 & 2.2 & $4 \mathrm{Wh} / \mathrm{m}^{\wedge} 2$ in 1998 & \\
\hline Refrigerator UEC & kWh/year & 461.2 & 421.9 & 458.9 & 422.3 & 380 & for $250 \mathrm{~L}-300 \mathrm{~L}$ \\
\hline \multicolumn{8}{|l|}{ Clothes washer } \\
\hline vertical & kWh/year & 35.88 & 32.9 & 23.9 & 28.1 & & \\
\hline horizontal & kWh/year & 92.4 & 60.9 & 61.36 & 51.5 & 21.9 to 40.2 & for $4.2 \mathrm{~kg}$ \\
\hline \multicolumn{8}{|l|}{ TV } \\
\hline black\& white & kWh/year & 38 & 63.8 & 38 & 63.8 & & \\
\hline color & $\mathrm{kWh} / \mathrm{year}$ & 125 & 243 & 125 & 243 & $\begin{array}{c}79 \\
\text { 4/ kvvi/IIIUIIII IUI } \\
\text { cooling, } \\
116 \mathrm{kWh} / \mathrm{month} \text { for }\end{array}$ & for capacity of \\
\hline Air Conditioner UEC & $\mathrm{kWh} / \mathrm{vear}$ & 387.6 & 245.6 & 375 & 248.9 & heating & $2.5 \mathrm{~kW}$ \\
\hline
\end{tabular}
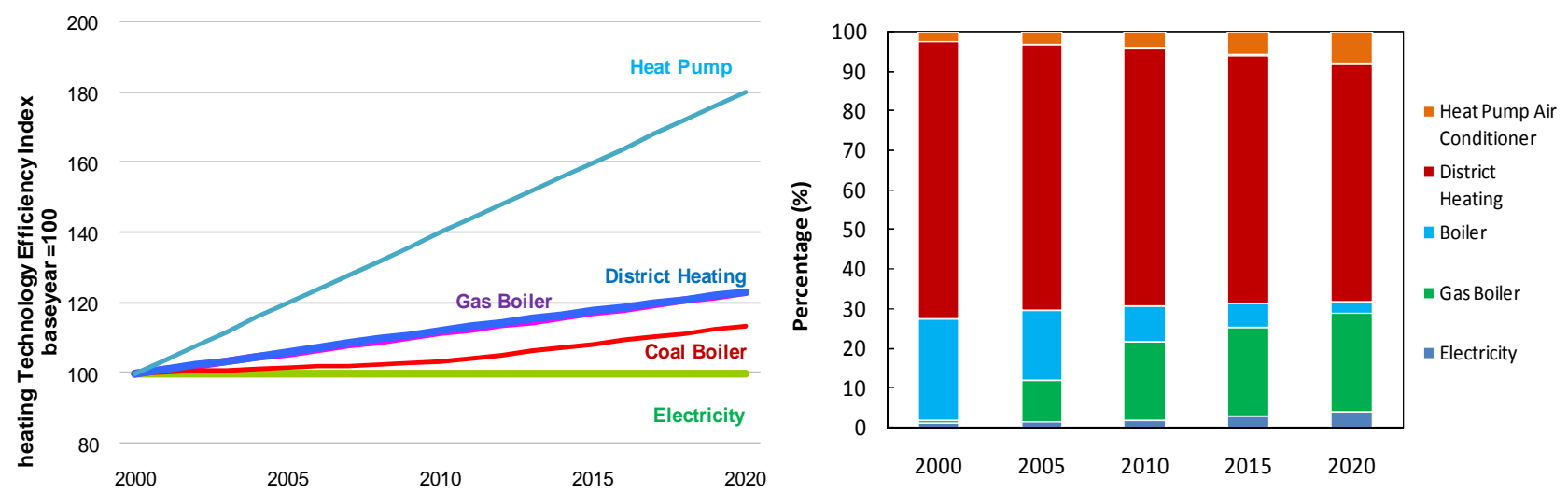

Figure 5 Efficiency of the Space Heating Technologies

Figure 6 Space Heating Technology Shift in Residential Building 

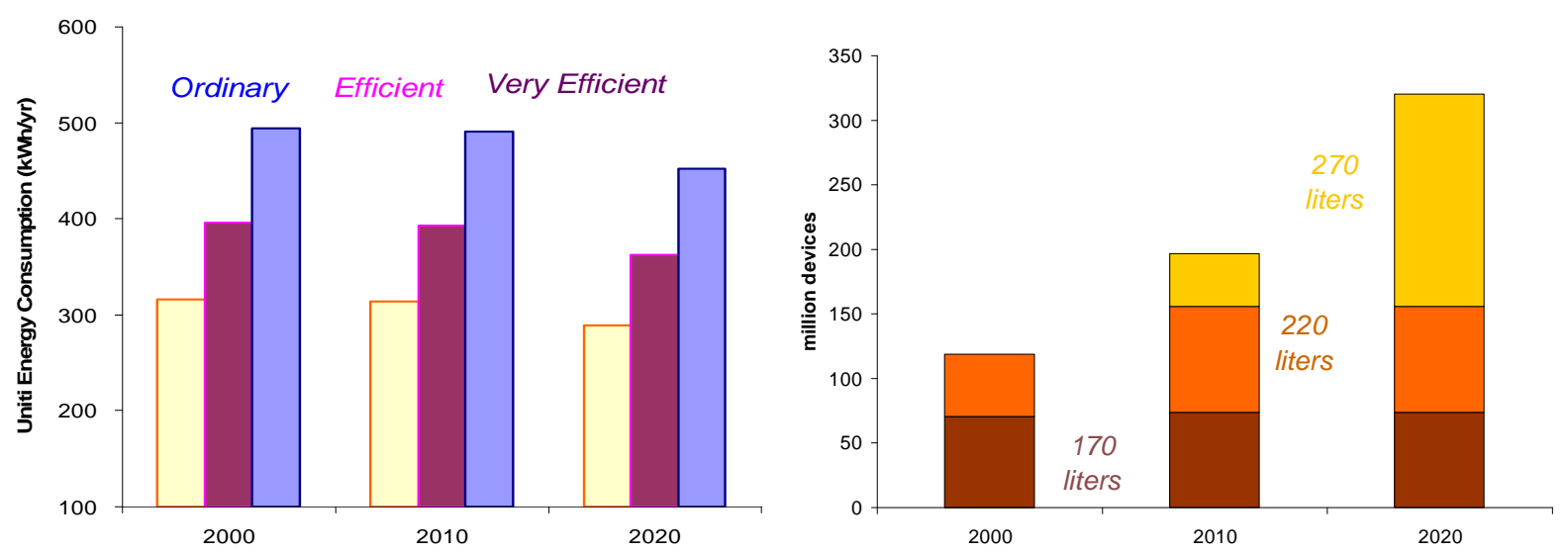

Figure 7 Refrigerator UECs by Efficiency Class

Figure $8 \quad$ Refrigerator Stock by Size
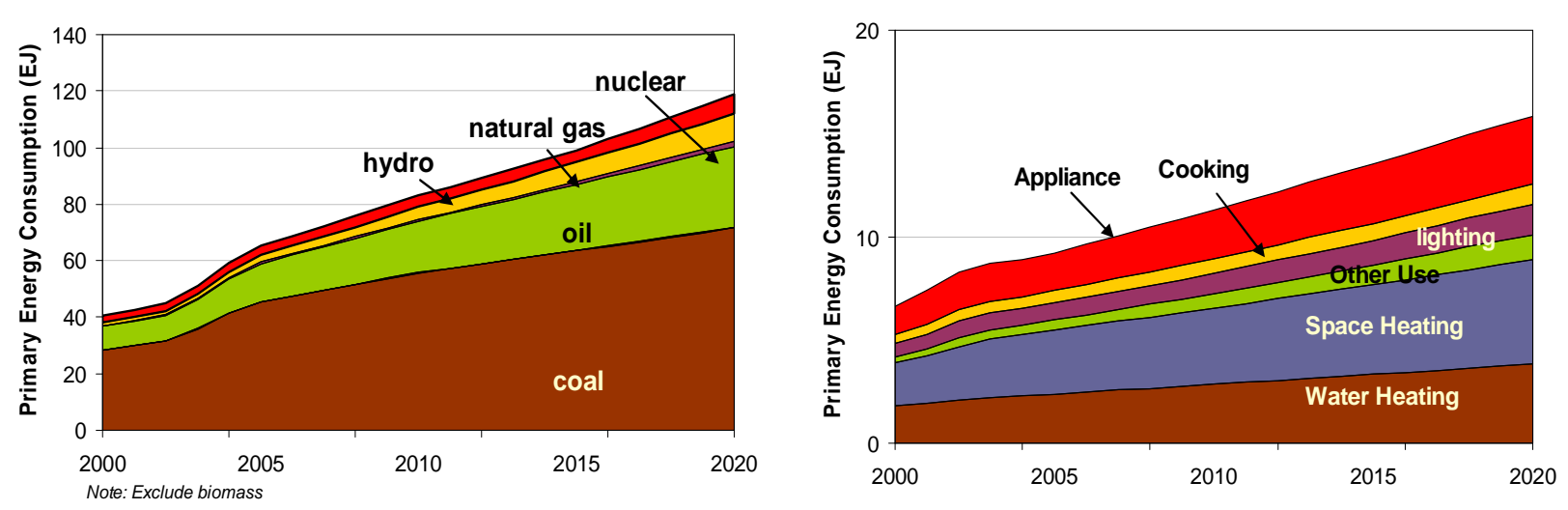

Figure 9 Primary Energy Projection by Fuel

Figure 1 Primary Energy Consumption by End-use) 